\title{
Faktor penentu kelakuan pusingganti pekerja dalam firma IT berstatus MSC Malaysia
}

\begin{abstract}
The resource-based perspective of entrepreneurship emphasises that highly-skilled employees are important resources in developing new products and in supporting high growth of technology-based firms. Therefore, human resources management issues, including reducing turnover and retaining employees are critical issues. The purpose of this study is to identify factors that influence the turnover behaviour among employees in Malaysian's MSC-status IT firms. Its data-gathering method was survey with the firms' human resource and top managers selected as respondents. A total of 500 questionnaires were mailed to IT firms with MSC-status. Out of this figure, 106 questionnaires were completed and returned, generating a response rate of $21 \%$. The results indicate that five factors influence the employees' turnover behavior, which are organisational, work-related, individual, employees-involvement and external factors. This study indicates that internal factors are the main effect in retaining employees in organizations, while to counter the influence of external factors on employees' turnover, an organization could raise their salary, offer more attractive work-incentives, and provide more flexible working hours.
\end{abstract}

Keyword: MSC-status IT firms; Employees; Turnover behaviour; Human resources management 